\title{
PENGELOLAAN RISIKO SOSIAL DALAM COST OF ADOPTION GERAKAN PEMBAHARUAN K.H. AHMAD DAHLAN
}

\author{
Nur Azizah Prastika \\ STID Al-Hadid, Surabaya \\ Nurazizahprastika123@gmail.com
}

\begin{abstract}
Abstrak: Dakwah adalah menyeruh kepada insan pada jalan kebaikan dan keselamatan. Namun, adanya risiko-risiko tertentu dalam menjalankan nilai yang baik kadang tidak diterima dengan mudah. Risiko-risiko tersebut dalam konsep pemasaran sosial disebut cost of adoption. Aktivis dakwah hari ini dapat belajar dari keberhasilan K.H. Ahmad Dahlan dalam gerakan pembaharuannya bidang pendidikan di masyarakat. Terdapat berbagai risiko atau cot of adoption yang diterima oleh pengikutnya, namun K.H. Ahmad Dahlan dapat mengelola risiko-risiko tersebut sehingga berhasil dalam menawarkan produk sosialnya di masyarakat. Studi ini bertujuan untuk mendeskripsikan risiko sosial dan pengelolaannya sebagai suatu cost of adoption dalam gerakan pembaharuan pendidikan K.H. Ahmad Dahlan. Pendekatan yang digunakan adalah deskriptif kualitatif kepustakaan. Hasil studi menunjukan bahwa risiko sosial ditanggung oleh adopter produk pembaharuan pendidikan K.H. Ahmad Dahlan sangat tinggi akibat penolakan keras gagasan tersebut oleh para pemuka agama. Pengelolaan yang dilakukan untuk mengatasi risiko sosial tersebut adalah dengan mengumpulkan dukungan dari kelompok elit masyarakat Yogyakarta, meliputi kalangan santri-priyayi, priyayi non santri dan pengusaha muslim untuk mengatasi risiko sosial yang dihadapi oleh sasaran dakwahnya.

Kata kunci: pengelolaan risiko, cost of adoption, gerakan pembaharuan, K.H. Ahmad Dahlan
\end{abstract}

\begin{abstract}
Propagation constitutes an effort of conveying the goodness and salvation to human beings. However, there are certain risks in implementing good values, which is not accepted easily. The risks, in the concept of social marketing, are called cost of adoption. Today da'wah activitists can learn from the success of K.H. Ahmad Dahlan's reforming movement in the field of education. There were various risks or cost of adoption which were suffered by hos followers. However, K.H. Ahmad Dahlan was able to manage those risks so that he succeeded in offering his social product in society. The study aims to describe social risks and their management as a cost of adoption in K.H. Ahmad Dahlan's educational reforming movement. The approach used is qualitative descriptive literature. The result of study shows that social risk taken by the adopter of educational reforming product - K.H. Ahmad Dahlan - was high because of the rejections from his idea by religious figures at that time. The management conducted to overcome the social risk was by gathering support from social elite in Yogyakarta, including elite Islamic students, elite non-Islamic students and Islamic businesspeople in order to overcome social risk encountered by his da'wah targets.
\end{abstract}


Keywords: risk management, cost of adoption, reforming movement, K.H. Ahmad Dahlan

\section{Pendahuluan}

Pemasaran sosial adalah cara merubah pandangan dan perilaku masyarakat ke arah yang lebih positif dengan menekankan pada ajakan dan persuasi bukan kekerasan dan paksaan. ${ }^{1} \mathrm{Hal}$ ini sejalan dengan tujuan dari proses dakwah dalam Islam yang ingin membawa perubahan positif bagi masyarakat melalui ajakan dan seruan yang bil hikmah. Sebagaimana diketahui bahwa dakwah merupakan usaha pergerakan pikiran dan perbuatan manusia untuk mengembangkan fungsi kerisalahan disamping kerahmatan, fungsi kerisahlahan berupa tugas menyampaikan din al-Islam kepada manusia, sedangkan fungsi kerahmatan adalah upaya menjadikan Islam sebagai rahmat bagi alam semesta. ${ }^{2}$

Namun demikian proses dakwah dan penyebaran nilai-nilai Islam yang sebetulnya membawa rahmat ini, tidak jarang justru mendapat penolakan dari masyarakat. Ada yang menolak sepenuhnya ada pula yang menerima sebagian dan menolak sebagian yang lain. Salah satu fenomena yang cukup banyak ditemui adalah fenomena berhijab. Banyak muslimah yang taat dalam menjalankan shalat, berpuasa dan berzakat, namun tidak mau menjalankan perintah berhijab. Padahal perintah berhijab sudah tertera jelas dalam Alquran.

\footnotetext{
1 Philip Kotler dan Eduardo L. Roberto, Social Marketing: Strategies for Changing Public Behavior, (New York: The Free Press, 1989), ix.

2 Siti Muriah, Metodologi Dakwah Kontemporer, (Yogyakarta: Mitra Pustaka, 2000),10.
}

Sebuah pemberitaan di Kompas mengungkap beberapa alasan para muslimah saat memutuskan untuk tidak berhijab. Terungkap bahwa beberapa dari mereka memang masih ragu tentang keharusan berhijab dalam Islam, mereka juga merasa belum mendapat hidayah atau merasa belum siap. Namun yang lainnya merasa bahwa ada banyak risiko yang harus mereka tanggung saat berhijab, mulai dari kekhawatiran dalam mengahadapi orang tua yang tidak sepakat, khawatir kesulitan mendapat pekerjaan, sulit mendapat jodoh, tidak modis lagi, berpenampilan jelek sampai dengan kerusakan rambut. ${ }^{3}$

Persoalan risiko dalam menjalankan perintah agama ini sama halnya dengan konsep cost of adoption dalam pemasaran sosial. Cost of adoption secara prinsip adalah risiko yang harus diterima oleh seseorang saat mereka hendak menjalankan sebuah perilaku tertentu. Dalam kasus berhijab di atas, kekhawatiran dalam mengahadapi orang tua yang tidak sepakat, khawatir kesulitan mendapat pekerjaan, sulit mendapat jodoh, tidak modis lagi, berpenampilan jelek sampai dengan kerusakan rambut yang dianggap sebagai risiko atau biaya yang harus dikorbankan adalah cost of adoption dalam mengadopsi atau menjalankan perintah berhijab. Diantara banyak cost of adoption yang diungkapkan, cost berupa pandangan

\footnotetext{
${ }^{3}$ Christina Andhika Setyani, "10 Alasan Perempuan Enggan Berhijab", KOMPAS.com, diakses 29 oktober 2018,

https://lifestyle.kompas.com/read/2013/07/23/1407 130/10.Alasan.Perempuan.Enggan.Berhijab
} 
negatif dari eksternal adalah yang paling besar dihadapi oleh para muslimah diatas.

Maraknya kajian baik berupa tablig akbar maupun melalui berbagai perangkat teknologi hari, termasuk yang mengangkat tema tentang kewajiban muslimah untuk berhijab ternyata belum sepenuhnya mampu mendorong para muslimah untuk berhijab. Walalupun kian hari jumlah muslimah terus meningkat namun tetap saja jumlah wanita muslimah yang belum memutuskan untuk berhijab masih jauh lebih banyak dari pada yang berhijab. Hal ini dapat menjadi sebuah kewajaran ketika memang konten-konten kajian yang selama ini ada masih banyak menekankan pada hukum berhijab, serta manfaatnya bagi para muslimah. Sedangkan berbagai risiko yang menjadi kekhawatiran para muslimah untuk berhijab belum banyak dijawab.

Dalam pemasaran sosial, permasalahan cost of adoption perlu dikelola atau managing cost of adoption. Managing cost of adoption adalah serangkaian cara yang dilakukan untuk mengatasi atau menjawab berbagai risiko dan pengorbanan yang harus ditanggung oleh pasar saat mereka menerima pemikiran atau perilaku baru yang ditawarkan. Risiko dan pengorbanan yang diatasi meliputi risiko moneter atau uang, juga risiko-risiko nonmoneter seperti pengorbanan psikologis (perasaan tidak nyaman dengan perilaku baru atau ketakutanketakutan tertentu), pengorbanan sosial (kekhawatiran tentang anggapan sosial jika ia berubah) dan pengorbanan waktu atau fisik lainnya yang harus dikeluarkan saat

\footnotetext{
${ }^{4}$ Majelis Diklitbang dan LPI PP Muhammadiyah, Satu Abad Muhammadiyah: Gagasan Pembaharuan Sosial Keagamaan, (Jakarta: Kompas, 2010), 39.
}

seseorang mengadopsi perubahan perilaku.

Dalam sejarah dakwah di Indonesia, K.H. Ahmad Dahlan adalah salah seorang pendakwah yang sangat terkenal dengan gagasan Islam pembaharuannya. Dimana, realisasi dari ide-ide pembaharuan yang dikemukakan Ahmad Dahlan pada masa awal pembentukan Muhammadiyah harus berhadapan dengan kelompok penentang yang sangat kuat sehingga tidak mengherankan sering terjadi ketegangan. ${ }^{4}$ Ketegangan ini yang menimbulkan munculnya risiko-risiko bagi mitra dakwah yang hendak mengikuti atau menjalankan gagasan pembaharuan yang dibawa oleh K.H. Ahmad Dahlan.

Salah satunya adalah gagasan tentang pembaharuan pendidikan Islam. Pendidikan Islam modern yang ditawarkan oleh K.H. Ahmad Dahlan kala itu mendapat penolakan keras dari masyarakat. Sekolah yang didirikan pada tahun 1911 di Kauman, Yogyakarta tersebut merupakan sekolah pertama yang mengintegrasikan pendidikan model barat dengan pendidikan Islam sekaligus. Sekolah ini mempunyai murid lakilaki dan perempuan sekaligus (coeducation). Mereka belajar menggunakan papan tulis dan kapur, bangku-bangku serta alat peraga. ${ }^{5}$

Kendati sekolah ini adalah upaya K.H. Ahmad Dahlan untuk menjawab ketertinggalan sistem pendidikan Islam kala itu, namun ternyata tidak mendapat sambutan yang baik dari masyarakat, kecuali beberapa pemuda. Pada tahap awal proses

\footnotetext{
${ }^{5}$ M.T. Arifin, Gagasan Pembaharuan Muhammadiyah dalam Pendidikan, (Jakarta: Dunia Pustaka Jaya, 1987), 217.
} 
belajar mengajar belum berjalan lancar. Selain ada penolakan dan pemboikotan dari masyarakat sekitarnya, para siswa yang hanya berjumlah delapan orang itu juga jarang masuk sekolah. ${ }^{6}$ K.H. Ahmad Dahlan juga pernah dikatakan "Kiai Kristen" karena telah mendirikan sekolah dengan cara baru ini. ${ }^{7}$ Saat itu bahkan salah seorang kiai dari Magelang mendatangi langsung sekolah yang didirikan oleh K.H. Ahmad Dahlan dan menyampaikan tegurannya seraya memberi label kafir pada K.H. Ahmad Dahlan. ${ }^{8}$

Sikap masyakarat yang demikian, tentu memberikan dampak bagi masyarakat yang hendak bersekolah di sekolah tersebut. Stigma kafir tentu juga akan dilekatkan pada orang-orang yang sepakat pada gagasan K.H. Ahmad Dahlan ini. Bagi umat muslim stigma kafir tentu adalah hal yang mereka hindari. Sebab hal tersebut artinya mereka keluar dari keyakinan mereka yang harusnya dipegang teguh dan menjadi landasan hidup yang utama.

Hal-hal diatas menunjukan adanya risiko bagi orang-orang yang hendak menerima gagasan pembaharuan K.H. Ahmad Dahlan. Stigma negatif dari masyarakat ini dalam pemasaran sosial kemudian diistilahkan dengan risiko sosial. Namun risiko ini dapat diatasi oleh K.H. Ahmad Dahlan. Pendirian sekolah yang pada awalnya menghadapi penolakan keras dari masyarakat, perlahan mulai diterima masyarakat. $\mathrm{Hal}$ ini dibuktikan dengan jumlah murid yang terus

\footnotetext{
6 Ibid., 23.

7 Sutrisno Kuntoyo, Kiai Haji Ahmad Dahlan dan Perserikatan Muhammadiyah (Jakarta: Balai Pustaka 1998), 82-83.

8 Mutiara, "Kendaraannya Orang Kafir", suaramuhammadiyah.id, diakses 19 Desember 2018, http://www.suaramuhammadiyah.id/2016/01/25/ke ndaraannya-orang-kafir/
}

meningkat. Jumlah murid yang awalnya hanya 8 setelah 6 bulan meningkat menjadi 20 orang. ${ }^{9}$ Sampai akhir 1920 jumlah siswa di semua sekolah Muhammadiyah adalah 787 orang, yang terdiri dari 572 siswa di empat Sekolah Angka 2, 17 siswa Al-Qismul Arga, dan 198 siswa Sekolah Agama. Pada tahun yang sama guru yang mengajar di sekolah Muhammadiyah berjumlah 32 orang. Pertambahan jumlah siswa yang sangat cepat pada waktu itu mendorong pimpinan Muhammadiyah untuk mendirikan gedung sekolah baru di Suronatan. ${ }^{10}$

Kesuksesan gerakan pembaharuan bidang pendidikan K.H. Ahmad Dahlan ini bahkan menjadikan Muhammadiyah sebagai organisasi yang memainkan peran besar dalam gerakan pendidikan Islam. Dalam bidang pendidikan, Muhammadiyah mengalami perkembangan cepat, terutama dari segi jumlah lembaga pendidikan yang dibangun. ${ }^{11} \quad$ Muhammadiyah menjadi alternatif bagi madrasah di satu sisi dan sekolah sekuler di sisi lain. John Legge bahkan mengatakan bahwa model sekolah Muhammadiyah telah memainkan peranan penting dalam konteks rekonsiliasi antara intelektual muslim dan cendekiawan barat. ${ }^{12}$ Bahkan kini partisipan berbagai jenis dan tingkat lembaga pendidikan Muhammadiyah kebanyakan bukan keluarga pengikut Muhammadiyah. Bagian terbesar dari murid atau mahasiswa pendidikan Muhammadiyah adalah

\footnotetext{
${ }^{9}$ Majelis Diklitbang dan LPI PP Muhammadiyah, Satu Abad., 23.

10 Ibid., 41.

11 Arief Subhan, Lembaga Pendidikan Islam Indonesia Abad Ke-20, (Jakarta: UIN Jakarta Press, 2009), 95.

12 Ibid., 132.
} 
pengikut Nahdlatul Ulama (Nu) dan kaum Abangan. ${ }^{13}$

Kajian mengenai proses dakwah K.H. Ahmad Dahlan telah banyak dilakukan, diantaranya adalah: (1) Pemikiran Teologi K.H. Ahmad Dahlan, tesis karya Susianti B. R. Sitepu ini bertujuan untuk membongkar sisi teologis dari pemikiran yang di bawa oleh K.H. Ahmad Dahlan. ${ }^{14}$ (2) Berikutnya adalah penelitian dengan judul The History of Muhammadiyah's Thought and Movement, Study on Personality and Idea of The Founding Figure (K.H. Ahmad Dahlan) yang menekankan pada sejarah lahirnya gagasangagasan pembaharuan dan pergerakan Muhammadiyah ditinjau dari kepribadian K.H. Ahmad Dahlan selaku pendiri Muhammadiyah..$^{15}$ (3) sedangkan penelitian dengan judul Thought KH. Ahmad Dahlan In the Field of Social and Educational memfokuskan pada pemikiran K.H. Ahmad Dahlan pada dimensi sosial dan pendidikan. ${ }^{16}$ (4) Kemudian tesis dengan judul Strategi Pegembangan Dakwah K.H. Ahmad Dahlan Di Yogyakarta Dan TGH. Muhammad Zainuddin Abdul Majid di Lombok, yang memaparkan tentang deskripsi strategi dakwah K.H. Ahmad Dahlan dan membandingkannya dengan strategi dakwah yang dilakukan oleh T.G.H. Muhammad Zainuddin Abdul Majid di Lombok. ${ }^{17}$

Dari sini dapat diketahui bahwa banyak penelitian sebelumnya yang membahas

${ }^{13}$ Majelis Diklitbang dan LPI PP Muhammadiyah, Satu Abad., xxxix.

${ }^{14}$ Susianti BR Sitepu, "Pemikiran Teologi K.H. Ahmad Dahlan" (Tesis, Universitas Negeri Sumatra Utara, 2016), v.

15 Fauji Koda, "The History of Muhammadiyah's Thought and Movement, Study on Personality and Idea of The Founding Figure (KH. Ahmad Dahlan)", mengenai pemikiran Muhammadiyah dan K.H. Ahmad Dahlan terutama dalam hal agama, sosial dan pendidikan. Adapula penelitian tentang strategi dakwah namun dan sudah dibadingkan dengan strategi dakwah ulama yang lain namun belum sampai pada teksni menjawab risiko-risiko bagi sasaran dakwahnya saat menerima pemikiran yang dibawanya. Untuk itu studi ini memfokuskan kajiannya pada proses cara mengatasi risiko atau managing cost of adoption yang dilakukan K.H. Ahmad Dahlan dalam rangka mendorong masyarakat menerima berbagai gagasan pembaharuan di bidang pendidikan, tepatnya pada tahun 1912 sampai dengan 1923 (selama masa periode K.H. Ahmad Dahlan memimpin Muhammadiyah), spesifiknya pada managing social cost-nya.

Studi ini adalah studi kualitatif deskriptif dengan pendekatan kepustakaan. Kualitatif deskriptif karena dalam penelitian ini bertujuan untuk memahami suatu realitas dalam hal ini risiko-risiko sosial yang diterima oleh jemaah atau adopter gagasan pembaharuan K.H. Ahmad Dahlan serta proses proses pengelolaan yang dilakukan untuk mengatasi risiko sosial tersebut. Pendekatan kepustakaan karena teknik pengumpulan data yang digunakan adalah melalui sumber-sumber kepustakaan terkait. Sumber rujukan utama yang digunakan adalah buku Satu Abad Muhammadiyah: Gagasan Pembaharuan Sosial Keagamaan yang dikeluarkan

International Journal of Scientific \& Technology Research, 8, (2017): 155.

16 Defti Arlen dkk, Thought KH. Ahmad Dahlan In the Field of Social and Educational, (Tesis, M.Pd., Universitas Lampung, 2014), 1.

17 Husnan Wadi, "Strategi Pegembangan Dakwah K.H. Ahmad Dahlan Di Yogyakarta Dan TGH. Muhammad Zainuddin Abdul Majid di Lombok" (Tesis, Universitas Muhammadiyah Surakarta, 2012), 4. 
langsung oleh Majelis Diklitbang dan LPI PP Muhammadiyah, walaupun bukan di tulis oleh K.H. Ahmad Dahlan sendiri, namun buku ini dikeluarkan langsung oleh organisasi Muhammadiyah sebagai wadah yang dibuat oleh Kiai Ahmad Dahlan untuk menjalankan gerakan dakwahnya. Sebagai tambahan dan triangulasi sumber data, digunakan pula buku-buku lain yang membahas tantang gerakan dakwah Kiai Ahmad Dahlan, meliputi: (1) Matahari Pembaharuan: Rekam Jejak K.H. Ahmad Dahlan; (2) Kiai Haji Ahmad Dahlan dan Perserikatan Muhammadiyah; (3) Gagasan Pembaharuan Muhammadiyah dalam Pendidikan; (4) Perjuangan dan Pengabdian Muhammadiyah; (5) Sejarah Pertumbuhan dan Perkembangan Lembaga-lembaga Pendidikan Islam di Indonesia; (6) Gerakan Modern Islam di Indonesia; (7) Studi Kemuhammadiyahan: Kajian Historis, Ideologi dan Organisasi; dan beberapa jurnal serta buku-buku lain yang menjelaskan tentang latar belakang gerakan berupa berbagai gagasan K.H. Ahmad Dahlan dalam hal pendidikan. Analisis data dilakukan secara kualitatif mulai dari pengumpulan data dari berbagai sumber yang telah ditetapkan, reduksi data analisis data dan terakhir penarikan kesimpulan.

\section{Pemasaran Sosial}

Menurut Kotler dan Roberto, "Social marketing is a strategy for changing behaviour. It combines the best element of the traditional approaches to social change in integrated planning and action framework and utilizes advances in

\footnotetext{
18 Ibid., 24.

19 P. Kotler and Zaltman, "Sosial Marketing: An Approach to Planned Sosial Change," Journal of Marketing, (August, 1971), 5.
}

communication technology and marketing skills. ${ }^{18}$ Pemasaran sosial adalah strategi untuk merubah perilaku. Pemasaran sosial mengkomunikasikan unsur atau elemen terbaik dari perubahan sosial yang menekankan pada pendekatan tradisional terkait dengan perencanaan yang terintegrasi serta rangkaian aksi dan pengembangan dalam penggunaan teknologi komunikasi serta kemampuan pemasaran.

Dalam kesempatan yang lain, Philip Kotler dan Gerald Zaltman juga menyampaikan bahwa social marketing adalah, "The design, implementation, and control of the programs calculated to influence the acceptability of sosial ideas and involving considerations of product planning, pricing, communication, distribution, and marketing research." ${ }^{19}$ Pemasaran sosial adalah sebuah design implementasi dan pengawasan terkait dengan program yang dirancang untuk mempengaruhi penerimaan sebuah ide sosial yang juga melibatkan pertimbangan perencanaan produk, komunikasi, distribusi juga riset pemasaran.

\section{Target Adopter}

Berbeda dari konsep pemasaran di bidang manajemen ataupun ekonomi, yang sasarannya disebut sebagai target konsumen, di lapangan kegiatan pemasaran sosial kelompok masyarakat diatas disebut target adopter dan bukan konsumen. Karena dalam pemasaran sosial orang tidak selalu harus mengosumsi suatu produk namun lebih ditekankan pada penerimaan suatu gagasan yang intinya adalah perubahan perilaku. ${ }^{20}$

\footnotetext{
20 Ricardi S. Adnan, Target Adopter Transformasi Pemasaran Sosial: Yang Mengubah Wajah Indonesia, (Jakarta: UI Press, 2012), 10.
} 


\section{Bauran Pemasaran Sosial}

Pemasaran sosial dapat juga dipandang sebagai sebuah proses mengembangkan produk yang tepat yang ditawarkan melalui proses promosi yang tepat pada sebuah tempat yang tepat dan harga yang sesuai. Empat bauran pemasaran sosial inilah yang menjadi kunci dari pemasaran sosial. ${ }^{21}$ Pertama, Produk. Produk dalam pemasaran sosial sebuah ide atau perilaku tertentu yang sebetulnya dibutuhkan oleh target adopter. Produk dalam pemasaran sosial juga dapat berupa nilai-nilai, kepercayaan, perasaaan, kebiasaan atau bahkan penggabungan beberapa hal tersebut, yang memang menjadi target perubahan dalam sebuah proses pemasaran sosial. ${ }^{22}$

Kedua, promosi. Promosi yang bermakna sebagai sebuah strategi komunikasi persuasif juga serangkaian taktik yang akan membuat produk yang sudah kita desain menjadi familiar dan menarik diterima/dijalankan oleh target adopter. Beberapa aktivitas promosi dalam pemasaran meliputi periklanan, penjualan personal, publisitas dan promosi penjualan. ${ }^{23}$ Ketiga, saluran distribusi. Saluran disrtibusi sebagai sebuah bauran pemasaran sosial berfungsi untuk membuat produk yang ditawarkan menjadi dapat diakses oleh target adopter. Tempat yang menjadi akses pasar dalam mendapatkan produk misal berupa ide tertentu atau tempat untuk menjalankan kebiasaan tertentu yang ditawarkan, seharusnya merupakan tempat yang mudah diakses oleh target adopter. ${ }^{24}$

\footnotetext{
${ }^{21}$ Kotler and Zaltman, "Sosial Marketing:" 7.

22 Ibid., 7.

23 Ibid., 7.

24 Ibid., 9.
}

Ketiga, harga. Harga adalah pengorbanan yang harus ditanggung target adopter saat mereka menerima ide atau kebiasaan yang ditawarkan. Pada dasarnya harga dalam pemasaran sosial tidak bisa diartikan sebagai pengorbanan berupa uang saja, namun hal hal di luar uang yang harus mereka korbankan saat target adopter menerima gagasan atau kebiasaan baru merupakan realitas harga dalam pemasaran sosial. ${ }^{25}$ Dalam literatur yang lain ada juga yang mengistilahkan harga sebagai cost of adoption, yang memiliki makna sama dengan harga yaitu pengorbanan yang harus ditanggung oleh target adopter saat mereka menerima gagasan atau kebiasaan baru. ${ }^{26}$

\section{Harga/Cost of Adoption dalam Pemasaran Sosial}

Pengertian price atau harga dalam konsep sosial marketing adalah biaya atau pengorbanan yang harus dikeluarkan oleh individu untuk mengadopsi perilaku yang ditawarkan. Dapat juga diartikan sebagai risiko yang harus ditanggung oleh target adopter saat mereka meninggalkan perilaku lamanya dan menggantinya pada perilaku baru yang ditawarkan. Kotler menjelaskan bahwa biaya yang dibutuhkan untuk mengadopsi suatu perilaku melingkupi monetary cost dan nonmonetary cost. ${ }^{27}$

Monetary cost berkaitan dengan biaya yang dikeluarkan untuk membeli produk-produk pendukung yang bersifat tangible. Biaya moneter adalah risiko berupa materi atau uang dengan jumlah tertentu yang harus dibayarkan atau dikeluarkan oleh target adopter saat mereka hendak menjalankan

\footnotetext{
25 Ibid., 9.

${ }^{26}$ Kotler dan Roberto, Social Marketing, 174.

27 Ibid., 182.
} 
pemikiran atau ide atau perilaku yang ditawarkan. ${ }^{28}$

Sedangkan nonmonetary cost merupakan risiko-risiko dalam bentuk nonuang, diantaranya meliputi risiko waktu, risiko psikologis, risiko sosial, risiko penggunaan dan risiko fisik. Risiko waktu biasanya muncul karena adanya waktu yang harus dikorbankan baik untuk mendapatkan informasi terkait dengan ide atau perilaku yang ditawarkan maupun waktu untuk menjalankan ide atau perilaku yang ditawarkan itu sendiri. Risiko psikologis adalah risiko berupa perasaan tidak nyaman, khawatir, sedih, dan lain-lain, yang muncul sebagai akibat menjalankan perilaku bari yang ditawarkan. Risiko penggunaan adalah risiko berupa akibat-akibat yang dirasakan langsung oleh target adopter seketika menggunakan atau menjalankan ide baru yang ditawarkan. Terakhir, risiko fisik, yaitu kerugian fisik yang harus ditanggung oleh target adopter karena menerima atau menjalankan ide atau perilaku baru yang ditawarkan.

Risiko sosial adalah risiko berupa pandangan sosial yang negatif dari masyarakat karena target adopter menjalankan perilaku baru yang ditawarkan. ${ }^{29}$ Risiko sosial juga dapat digambarkan sebagai sebuah kondisi dimana penerimaan gagasan tentang perilaku baru yang bisanya tidak mendapatkan dukungan sosial atau bertentangan dengan norma sosial yang berlaku saat itu. ${ }^{30}$

\footnotetext{
28 Ibid., 182.

29 Ibid., 182

30 R. Craig Lefebvre, Social Marketing and Social Change: Strategies and Tools for Health, Well-Being and Environtment, (California: Jossey-Bass:2013), 326.
}

\section{Managing Cost of Adoption dalam Pemasaran Sosial}

Dalam mengelola biaya adopsi atau risiko karena menjalankan ide atau perilaku baru yang ditawarkan dalam pemasaran sosial terdapat beberapa hal yang dapat dilakukan diantaranya, pertama, managing monetary cost. ${ }^{31}$ Dalam mengelola risiko moneter yang pertama kali harus di pertimbangkan adalah tujuan penetapan harga moneternya terlebih dahulu. Ada lima tujuan penetapan harga moneter dalam pemasaran sosial, yaitu untuk meningkatkan keuntungan, mengembalikan biaya produksi, memaksimalkan jumlah target adopter yang mengkonsumsi produk atau ide dan perilaku yang ditawarkan, keseimbangan atau kesetaraan sosial, atau justru mengurangi tingkat konsumsi produk tertantu. Setelah menetapkan tujuan penetapan harga, berikutnya adalah membuka berbagai alternatif harga moneter berdasarkan biaya produksi yang dibutuhkan, harga dari produk pesaing dan tingkat sensitivitas target adopter terhadap harga moneter.

Kedua, managing time cost. ${ }^{32}$ Untuk mengurangi risiko waktu atau jumlah waktu yang harus dikorbankan oleh target adopter untuk mendapatkan informasi atau untuk menjalankan ide atau perilaku yang ditawarkan ada beberapa alternatif model pengelolaan. Alternatif yang pertama jika pengorbanan waktu muncul karena keharusan melakukan perjalanan demi mendapatkan informasi atau menjalankan ide atau perilaku yang ditawarkan, maka pemasar dapat menata ulang saluran

\footnotetext{
31 Ibid.,174-181.
}

32 Ibid., 182. 
distribusi yang selama ini digunakan agar berada lebih dekat dengan target adopter, sehingga dapat mengurangi pengorbanan waktu yang harus dikeluarkan. Bisa juga dengan menambah jumlah saluran distribusi sehingga lebih banyak tempat yang dekat yang dapat diakses oleh target adopter. Sedangkan alternatif yang kedua bisa juga dengan mengelola proses komunikasinya, pemasar dapat menggunakan media-media tertentu yang lebih mudah diakses oleh target adopter atau bahkan melakukan kontak secara personal dengan target adopter, dengan mandatangi langsung target adopter di lokasi mereka.

Ketiga, managing perceived risks. ${ }^{33}$ Beberapa model atau alternatif dalam mengelola risiko penerimaan gagasan atau perilaku baru diantaranya: (a) Dalam mengurangi atau menurunkan risiko psikologis akibat menjalankan ide atau perilaku baru yang ditawarkan, maka pemasar sosial dapat menyusun atau mencoba membongkar manfaat-manfaat psikologis lain yang dapat disematkan pada produk (ide atau perilaku) yang ditawarkan; (b) untuk menurunkan risiko sosial dapat dilakukan dengan mengumpulkan dukungan dari pihak-pihak yang memiliki kredibilitas tinggi yang akan mampu mempengaruhi stigma masyarakat menjadi jauh lebih positif terhadap ide atau perilaku yang ditawarkan. Stigma yang awalnya diterima oleh target adopter akan hilang atau minimal terkurangi, sehingga target adopter akan lebih yakin dalam menerima atau menjalankan ide dan perilaku yang ditawarkan; (c) untuk menurunkan risiko karena dampak penggunaan atau proses menjalankan ide dan perilaku yang ditawarkan, pemasar dapat memberikan informasi yang lengkap tentang dampak penggunaan yang sebetulnya tidak merugikan atau berbahaya. Lebih baik lagi jika pemasar dapat memberikan kesempatan mencoba secara gratis, sehingga mereka dapat memiliki pengalaman langsung merasakan ide atau perilaku yang ditawarkan, dan pada akhirnya juga merasakan langsung manfaat yang sebenarnya terkandung dari tawaran pemasar; (d) dalam mengelola atau mengatasi risiko fisik, dapat diatasi dengan mengumpulkan dukungan legal atau resmi dari institusi berwenang yang mengawasi atau dianggap ahli dalam hal terkait.

\section{Pengelolaan Risiko Sosial dengan Menggalang Dukungan Sosial Leader Opinion.}

Fokus dalam studi ini adalah pada pengelolaan risiko sosial dalam cost of adoption. Secara teoretis, risiko sosial dapat diatasi dengan mengumpulkan dukungan dari pihak-pihak yang memiliki kredibilitas tinggi sehingga mampu mempengaruhi masyarakat. Pihak-pihak itulah yang disebut leader opinion di masyarakat. Dalam hal dukungan sosial untuk menjalankan sebuah gagasan pembaharuan Everret M. Rogers menawarkan beberapa pandangannya seputar pengukuran leadership opinion and networks links, characteristics of opinion leaders, communication network penyebaran gagasan pembaharuan atau diffusion of Innovation.

Everett M. Rogers berpandangan bahwa opinion leadership adalah tingkat di mana seseorang dapat mempengaruhi secara

33 Ibid., 182. 
informal sikap atau perilaku individu lain dengan cara tertentu. Pemimpin opini memainkan peran penting dalam mengaktifkan jaringan penyebaran gagasan pembaharuan. Konsep kepemimpinan opini berasal sebagai bagian dari model dua langkah aliran, yang berhipotesis bahwa pesan komunikasi mengalir dari sumber, melalui saluran media massa, ke pemimpin opini, yang kemudian meneruskannya kepada pengikut. ${ }^{34}$

Ciri-ciri pemimpin opini diantaranya adalah mereka memiliki memiliki partisipasi sosial yang lebih besar, status sosial yang lebih tinggi, kapasitas yang lebih besar dalam hal akses media massa dan lebih banyak inovasi. Dalam hal inovasi atau pembaharuan, pemimpin opini memang pihak yang menyesuaikan diri lebih dekat dengan norma-norma sistem dari pada pengikut mereka. Namun mereka juga merupakan golongan terdepan dalam hal penerimaan gagasan pembaharuan yang memang memberikan banyak manfaat bagi masyarakat. ${ }^{35}$ Jika Kotler dan Roberto Kolter dan Roberto menawarkan sebuah konsep pencarian dukungan dari pihak-pihak yang memiliki kredibilitas tinggi, maka Everett $\mathrm{M}$. Rogers mengistilahkan pihak-pihak ini sebagai leader opinion.

Sebagaimana disebutkan sebelumnya, leader opinion merupakan pihak yang paling terdepan dalam menerima bahkan menciptakan gagasan pembaharuan dimasyarakat. Hal ini karena mereka merupakan golongan yang memiliki partisipasi lebih aktif di masyarakat dibandingkan dengan golongan yang lain. Partisipasi atau peran ini ditandai dengan sikap aktif mereka menyelesaikan persoalan-persoalan yang ada di

\footnotetext{
34 Everett M. Rogers, Diffusion of Innovation, (New
} York: The Free Press, 1983), 310. masyarakat. Jika gagasan pembaharuan atau inovasi yang ditawarkan dapat memecahkan masalah mereka akan menerimanya bahkan menyebarkannya ke masyarakat. Sehingga cara untuk mendapatkan dukungan ddari golongan ini adalah dengan menunjukan bahwa gagasan pembaharuan yang dibawa merupakan solusi bagi masyarakat.

Dalam hal penyebaran gagasan pembaharuan, leader opinion memainkan perannya dalam jaringan atau struktur komunikasi di masyarakat. Jaringan atau struktur komunikasi di masyarakat ini memiliki pola berdasarkan aliran komuikasi atau pesan di masyarakat. Berhubungan erat dengan kedekatan antara leader opinion dan pengikutnya. Kedekatan ini akan menimbulkan adanya jaringan komunikasi personal yang kemudian memungkinkan leader opinion mempengaruhi perilaku pengikutnya. Sebagai tambahan, dalam teori pembelajaran sosial juga diketahui bahwa individu belajar dari orang lain yang mereka amati, yang kemudian mereka tiru dengan mengikuti perilaku yang serupa (tetapi tidak harus identik). Pemodelan sosial seperti itu sering terjadi dalam jaringan difusi. ${ }^{36}$ Dalam hal ini tentu saja orang-orang yang diikuti dan diamati adalah para leader opinion di masyarakat. Jika sang leader opinion menawarakn gagasan pembaharuan pada pengikut-pengikutnya dan menunjukan penerimaan mereka terhadap gagasan pembaruan tertentu, maka hal ini akan memicu penerimaan sebuah gagasan pembaharuan secara lebih luas di masyarakat.

Berdasarakan landasan teori di atas, dapat disusun kerangka konseptual pengelolaan

35 Ibid., 310.

36 Ibid., 310 
risiko sosial dalam cost of adoption, yaitu: (a) memilih pihak-pihak dengan kriteria leader opinion sebagaimana diatas sebagai pendukung gagasan pembaharuan yang ditawarkan; (b) mendapatkan dukungan dari pihak - pihak tersebut, dengan menawarkan inovasi atau gagasan pembaharuan pada mereka dengan menekankan pada manfaat bagi masyarakat; (c) mendorong partisipasi aktif mereka dalam menyebarkan gagasan pembaharuan yang ditawarkan pada masyarakat. Model jaringan komunikasi yang muncul karena kedekatan antara leader opinion dengan pengikutnya merupakan bagian dari pemanfaatan yang dapat digunakan untuk penyebaran gagasan pembaharuan.

Gerakan Pembaharuan K.H. Ahmad Dahlan dalam Bidang Pendidikan

\section{Latar Belakang dan Tujuan}

Ahmad Dahlan hidup pada masa kekuasaan Mangkubumi (Sultan Hamengku Buwana I). Saat itu keraton menjadi simbol eksistensi kekuasaan Islam, meski berada dalam penguasaan Belanda. Sebagaimana kerajaan Islam di Jawa sebelumnya, seperti Demak, Jipang, Pajang, setiap keraton memiliki masjid atau alun-alun. Masjid inilah yang nantinya memegang peranan penting dalam membangun kebudayaan Islam, termasuk dipergunakan oleh sultan berhubungan dengan bawahannya dan masyarakat umum. ${ }^{37}$

Ahmad Dahlan dilahirkan di Yogyakarta pada tahun 1868 Miladiyah dengan nama

37 Adaby Darban, Sejarah Kauman; Menguak Kampung Muhammadiyah, (Yogyakarta, Persatuan 2000), 101.
Muhammad Darwis, anak dari K.H. Abu Bakar bin Kiai Sulaiman, khatib di Masjid Sultan kota itu. Ibunya adalah Siti Aminah binti K.H. Ibrahim, penghulu besar di Yogyakarta. ${ }^{38}$ Ahmad Dahlan kemudian juga diangkat menjadi ketib amin (pemberi khotbah) setelah ayahnya meninggal dunia. Sebagaimana pejabat keagamaan keraton yang lain, Ahmad Dahlan tinggal di kampung Kauman. Kauman memang disediakan bagi para pejabat istana yang punya tanggungjawab urusan keagaamaan Kesultanan.

Bagi Ahmad Dahlan kala itu, keadaan umat Islam di Yogyakarta sudah menyimpang dari ajaran yang sesungguhnya yakni tidak sesuai dengan Alquran dan Hadis. Pemahaman Islam sudah bercampur dengan bidah, tahayul dan khufarat. Masyarakat Yogyakarta kala itu walaupun mereka mayoritas beragama Islam, namun mereka sangat jauh dari Alquran, pada akhirnya praktik keagamaan yang dijalankan justru bercampur dengan tradisi yang bukan bersumber dari Islam, seperti ritual membakar kemenyan, mempercayai kekuatan azimat (jimat), dan memintaminta kepada makam leluhur, dimana semua ini dianggap sebagai ajaran Islam oleh masyarakat. ${ }^{39}$

Masyarakat Yogyakarta kala itu juga meyakini kiai sebagai sumber berkah yang manjur. Di antara yang dianggap membawa berkah dan memiliki kekuatan magis adalah para wali. Akibatnya makam mereka menjadi situs ziarah demi mencari berkah. Beberapa kiai seringkali diminta untuk

38 Junus Salam, Gerakan Pembaharuan Muhammadiyah, (Tangerang: Al-Wasat Publising House, 2009), 56.

39 Mulkhan, Ajaran dan Pemikiran Ahmad Dahlan, 238. 
membuatkan azimat, menyeembuhkan sakit, memimpin upacara selamatan dan melakukan pengusiran setan..$^{40}$ Di Kauman, K.H. Ahmad Dahlan berdiri di tengah lingkungan itu. Di satu pihak ia menghadapi Islam-sinkretik yang diwakili oleh kebudayaan Jawa, dengan keraton, dan golongan priyayi sebagai pendukungnya dan di pihak lain menghadapi Islam tradisional yang tersebar di pedesaan dengan kiai dan pesantrennya. ${ }^{41}$

Kondisi ini juga berdampak pada kemunduran dalam bidang pendidikan, umat Islam waktu itu yang tenggelam dalam kejumudan (stagnasi), kebodohan, serta keterbelakangan. Ahmad Dahlan berpandangan ada problem yang mendasar berkaitan dengan lembaga pendidikan di kalangan umat Islam, khususnya lembaga pendidikan pesantren. Problem ini berkaitan dengan proses belajar mengajar, kurikulum dan materi pendidikan. Dalam proses belajar mengajar, sistem yang dipakai masih menggunakan sorogan dan weton, guru dianggap sebagai kebenaran yang tidak boleh dikritisi. Kondisi ini membuat pengajaran nampak tidak demokratis. Fasilitas-fasilitas modern yang sebetulnya baik untuk digunakan, namun malah dilarang untuk dipakai karena menyamai orang kafir. Hal yang sama dengan orang kafir, maka ia termasuk golongan kafir juga. ${ }^{42}$
Di bawah kolonialisme Belanda pendidikan masih terbatas pada calon-calon pamong praja. Sementara anak-anak aristokrat atau priyayi, ada yang dididik dalam rumahnya sendiri, pendidikannya ditujukan untuk mempertiggi budi pekerti, akhlakul karimah dan kepandaian bergaul, ditambah dengan adat istiadat nenek moyang. Bahkan untuk kaum wanita, pelajarannya hanya terbatas kepada pengetahuan kehidupan dalam rumah tangga, yang tujuannya kelak dapat menjadi istri yang baik. ${ }^{43}$ Sekolah yang didirikan kolonial ini tergolong sekolah yang sekuler, yang mengedepankan ilmu-ilmu keduniawian tanpa memasukan unsur agama atau keakhiratan sama sekali. ${ }^{44}$ Akibatnya lulusan dari sistem pendidikan ini tergolong maju secara pengetahuan umum, namun tidak memiliki pondasi agama yang kuat.

Tapi dari kesemuanya itu yang paling menderita adalah rakyat jelata, karena pada umumnya mereka tidak mampu mengenyam pendidikan. Sehingga keberadaan pondok pesantren saat itu menjadi pilihan satu-satunya bagi rakyat jelata. ${ }^{45}$ Sedangkan pendidikan di pondok pesantren adalah sebagaimana disampaikan di atas. Pada permulaan abad ke-20, jurang yang memisahkan antara lulusan dua sistem pendidikan yang sangat berbeda tersebut nampak sangat jelas sekali dalam kegiatankegiatan sosial seperti dalam berbicara, berpakaian dan cara berfikir. ${ }^{46}$

\footnotetext{
43 Hery Sucipto, K.H. Ahmad Dahlan Sang Pencerah, Pendidik dan Pendiri Muhammadiyah, (Jakarta: Best Media Utama, 2010), 113-114

44 Ibid., 114.

45 Ibid., 114.

46 Din Syamsuddin, Muhammadiyah Kini dan Esok, (Jakarta: Pustaka Panjimas, 1990), 222.
} 
Untuk itulah selain dalam rangka memajukan umat Islam yang sudah demikian tertinggal, Ahmad Dahlan juga ingin menyelesaikan kesenjangan antara dua model pendidikan diatas. Hal ini sebagaimana disebutkan oleh Ruswan dalam penelitiannya, "One of the Muhammadiyah educational objectives was the elimination of the gap between Dutcheducated scholars, who were generally aristocrats, and the religious-educated scholars, the graduates of the pesantren. The former accused the latter of 'conservatism,' 'traditionalism' and other pejorative attributes." 47

\section{Produk Sosial yang Ditawarkan}

Untuk mencapai tujuan pembaharuan di bidang pendidikan tersebut, Ahmad Dahlan kemudian beranggapan bahwa perlu adanya tempat pendidikan yang mengajarkan ilmu umum dan ilmu agama secara Bersamasama. ${ }^{48}$ Untuk itu kemudian Ahmad Dahlan mendirikan sekolah tahun 1911 di Kauman Yogyakarta. Sekolah ini mempunyai muridmurid laki-laki dan prempuan sekaligus (coeducation) yang diajar dengan menggunakan papan tulis dan kapur, bangku-bangku serta alat peraga. Sekolah ini merupakan sekolah tingkat dasar yang berawal dari sebuah pengajian. Pelaksanaan penyelenggaraan pendidikan seperti tersebut di kalangan kaum pribumi Jawa adalah yang pertama kali, yang berusaha untuk menggabungkan sistem pengajaran pesantren dengan Barat. ${ }^{49}$ Berikut ini aspek detil konsep sekolah yang digagas dan ditawarkan ke masyarakat:

47 Ruswan, "Colonial Experience and Muslim Educational Reforms: A comparation of The Aligarh And The Muhammadiyah Movements" (Tesis, McGill University, 1997), 87.

48 Sucipto, K.H. Ahmad Dahlan., 119.
Pertama, kurikulum pembelajaran. Muatan kurikulum sekolah yang ditawarkan memberikan porsi yang besar untuk ilmuilmu umum. Sedang dalam aspek keagamaan minimal alumni sekolah Muhammadiyah dapat melaksanakan ibadah salat lima waktu, dan salat-salat sunah lainnya, membaca kitab suci Alquran dan menulis huruf Arab (Alquran), mengetahui prinsip-prinsip akidah dan dapat membedakan bidah, khurafat, syirik dan muslim muttabi' (pengikut) dalam pelaksanaan ibadah. ${ }^{50}$

Kedua, materi pembelajaran. Dalam hal materi pembelajaran akhirnya diperlukan pembahasan mengenai Alquran dan Hadis, membaca, menulis, berhitung, ilmu bumi dan menggambar. Materi Alquran dan Hadis meliputi: ibadah, persamaan derajat, fungsi perbuatan manusia dalam menentukan nasibnya, musyawarah, pembuktian kebenaran Alquran dan Hadis menurut akal, kerjasama antar agama-kebudayaankemajuan peradaban, hukum kausalitas perubahan, nafsu dan kehendak, demokratisasi dan liberarisasi, kemerdekaan berfirkir, dinamika kehidupan dan peranan manusia di dalamnya dan akhlak. $^{51}$

Ketiga, metode kepengajaran. Metode kepengajaran yang digunakan Ahmad Dahlan di sekolahnya mengacu pada metode pengajaran sekolah pemerintah milik Belanda. ${ }^{52}$ Pengajaran satu per satu sebagamana di pesantren di ganti dengan sistem kelas. Tujuan pembelajaran juga

\footnotetext{
${ }^{49}$ M.T. Arifin, Gagasan Pembaharuan., 217.

50 Sucipto, K.H. Ahmad Dahlan., 120.

51 Ibid., 120.

52 Ibid., 124.
} 
menekankan pada pemahaman siswa tentang materi pembelajaran bukan sekedar menghafal. Bahkan murid-murid di sekolah ini juga diberi kebebasan untuk bertanya. Sebagaimana juga di sekolah pemerintah Belanda, siswa di sekolah ini juga mendapatkan pengukuran hasil capaian pembelajaran melalui ujian reguler, yang akan menentukan siswa tersebut dapat lanjut tingkat pembelajaran atau tidak. ${ }^{53}$

Keempat, guru. Guru di sekolah Muhammadiyah ini diambil dari anggota Muhammadiyah dan juga Boedi Oetomo bukan kiai sebagaimana di pesantren. Guru di Sekolah Muhammadiyah juga mendapat gaji secara profesional dari proses mereka mentransfer pengetahuan dan membantu murid-murid belajar. ${ }^{54}$ Kelima, peserta didik. Dalam hal peserta didik muhammadiyah juga memberikan kesempatan yang sama baik bagi siswa laki-laki maupun perempuan untuk mengenyam pendidikan, baik dalam hal materi pembelajaran maupun dalam hal capaian tingkat pendidikannya. ${ }^{55}$

\section{Target Adopter}

Berangkat dari latar belakang gerakan pembaharuan bidang pendidikan dan konsep produk sosial yang ditawarkan, maka dapat diketahui bahwa persoalan yang dipotret adalah kebutuhan pendidikan yang integral antara perkembangan ilmu pengetahuan barat dengan pengetahuan agama. Dimana pendidikan ini tidak bisa didapatkan secara sempurna baik oleh kalangan priyayi yang mengenyam pendidikan barat atau rakyat jelata yang

53 Ruswan, "Colonial Experience and Muslim Educational Reforms: A comparation of the Aligarh and the Muhammadiyah Movements" (Tesis, McGill University, 1997), 83.

54 Ibid., 83. hanya mampu menempuh pendidikan pesantren. Baik laki-laki maupun perempuan. Sehingga, semua kelompok inilah yang menjadi target adopter dari gagasan pemabaharuan pendidikan Ahmad Dahlan.

\section{Risiko Sosial dalam Cost of Adoption Gerakan Pembaharuan Pendidikan K.H. Ahmad Dahlan}

Namun demikian konsep pembaharuan pendidikan yang digagas Ahmad Dahlan ini tidak disambut baik oleh masyarakat, kecuali beberapa pemuda. Pada tahap awal proses belajar mengajar belum berjalan lancar. Selain ada penolakan dan pemboikotan dari masyarakat sekitarnya, para siswa yang hanya berjumlah delapan orang itu juga jarang masuk sekolah. ${ }^{56}$

Dalam berbagai kesempatan Ahmad Dahlan menyampaikan ide pembaharuan pendidikan yang akan diwujudkan lewat sekolah muhammadiyahnya ini, termasuk kepada para santri yang belajar di Kauman dan penduduk Kauman secara umum. Namun sebagian besar dari mereka bersifat acuh tak acuh, bahkan ada yang secara tegas menolak ide pendidikan sistem sekolah tersebut karena dianggap bertentangan dengan tradisi dalam agama Islam. Akibatnya, para santri yang selama ini belajar kepada Ahmad Dahlan satu per satu berhenti. ${ }^{57}$

Adanya kondisi yang demikian menunjukan bahwa bukan hanya Ahmad Dahlan yang

55 lbid., 84.

56 Majelis Diklitbang dan LPI PP Muhammadiyah, Satu Abad., 23.

57 Ibid., 23. 
menjadi sasaran penolakan masyarakat melainkan juga kelompok target adopter gagasan pembaharuan Ahmad Dahlan. Mereka ikut terkena dampak dari masyarakat yang tidak sepakat dengan gagasan tersebut. Jika ditinjau dari bentuk respon negatif masyarakatnya sendiri yang bukan hanya sekedar acuh tak acuh, melainkan sampai pada penolakan dan pemboikotan, tentu menjadi sangat wajar para santri dan murindnya juga mendapat respon serupa.

Adanya konteks tidak langsung berupa penyebaran gagasan pembaharuan Ahmad Dahlan di bidang keagamaan yang dilakukan sebelum penyebaran gagasan pembaharuan dibidang pendidikan juga menjadi alasan mengapa respon masyarakat menjadi demikian. Sebelumnya Ahmad Dahlan sebagai Ketib Amin Keraton Yogyakarta melakukan usaha pemurnian Islam di kalangan abdi dalem keraton.

Ahmad Dahlan melalui khotbahnya maupun melalui diskusi-diskusi dengan para pemuka agama keraton banyak menyampaikan pandangan pembaharuannya tersebut. Ahmad Dahlan berupaya memisahkan praktik-praktik budaya nonagama dengan praktek kegamaan yang sebenarnya. Dimana paktik demikian saat itu telah sangat mengakar di masyarakat dan mendapat dukungan kuat baik dari pejabat keraton maupun para ulama. Usaha pemurnian itu meliputi pembenaran arah kiblat, penyerderhanaan upacara slametan dan ibadah, penyederhanaan makam, menghilangkan kebiasaan ziarah ke makam orang suci dengan maksud meminta berkah pada mereka, dan sebagainya. Usaha-usaha

58 Suyoto dkk, Pola Gerakan Muhammadiyah Ranting, (Yogyakarta: UMG Press, 2005), 69. diatas mengancam secara langsung kekuasaan, prestise, dan kepentingan sosial ekonomi pegawai-pegawai keagamaan. ${ }^{58}$ Bahkan dalam kasus penentuan arah kiblat, Kanjeng Kiai Penghulu sampai mengeluarkan perintah untuk membogkar surau Ahmad Dahlan yang arah kiblatnya tidak sama dengan arah kiblat Masjid Besar Keraton, yang tentu saja perintah ini kemudian di tolak oleh Ahmad Dahlan. Namun pada akhirnya surau itu dibongkar secara paksa pada malam hari itu juga. ${ }^{59}$

Kondisi ini memberikan gambaran siapa saja pihak-pihak yang menolak gagasan pembaharuan Ahmad Dahlan. Gerakan pembaharuan Ahmad Dahlan di bidang pendidikan ini sebetulnya secara otomatis merupakan kritik keras pada pendidikan pesantren yang selama ini menjadi tradisi di masyarakat dan dipertahankan oleh para pemuka agama di masyarakat. Menjadi sangat wajar jika pada akhirnya kelompok yang paling keras penolakannya pada gagasan pembaharuan Ahmad Dahlan adalah kelompok ini.

Padahal posisi pemuka agama sekaligus pajabat keagamaan ini di masyarakat merupakan posisi yang cukup penting dan dianggap paling berwenang dalam mengurusi soal keagamaan, karena mereka mendapat wewenang langsung dari Sultan bahkan mereka mendapatkan gaji dan gelar kehormatan dalam menjalankan tugasnya tersebut. Sikap dan pandangannya terhadap sebuah fenomena keagamaan di masyarakat tentu menjadi perhatian bahkan pertimbangan yang diikuti oleh segenap masyarakat.

\footnotetext{
${ }^{59}$ Majelis Diklitbang dan LPI PP Muhammadiyah, Satu Abad., 19-20.
} 
Sikap negatif kelompok ini salah satunya tercermin saat proses pendirian organisasi Muhammadiyah. Saat itu Ahmad Dahlan hendak mendirikan organisasi Muhammadiyah untuk mengelola sekolah yang ia dirikan. Pemerintah kolonial Belanda sebagai pihak yang berwenang mengeluarkan izin pendirian organisasi memberikan salah satu syarat berupa persetujuan dari Sultan, dan Sultan menyerahkan persoalan tersebut pada Hoofd Penghulu, H. Muhammad Khalil Kamaludiningrat atau Kiai penghulu yang kala itu memerintahkan pembongkaran surau Ahmad Dahlan. Hasilnya permohonan izin tersebut di tolak. Walaupun setelah mendapat penjelasan lebih lanjut pada akhirnya penolakan dibatalkan dan izin diberikan. ${ }^{60}$

Selain itu anggota keluarga, para ulama dan penduduk Kauman juga tidak menyetujui tindakan dan sikap Ahmad Dahlan. Mereka tidak mengerti sikap tersebut, dikatakannya bahwa Ahmad Dahlan telah menyimpang dari ajaran agama Islam, dan telah murtad dari garis ajaran agama yang benar. ${ }^{61}$ Mereka yang tidak menyetujui Ahmad Dahlan menganjurkan agar beliau disisihkan dari pergaulan. ${ }^{62}$ Peristiwa penolakan permohonan izin ini ternyata disebabkan karena ketidakpahaman Kiai Penghulu terkait dengan istilah dalam surat pengajuan izin serta perasaan antipati pada Ahmad Dahlan karena masih teringat persoalan arah kiblat beberapa waktu yang lalu. ${ }^{63}$ Ahmad Dahlan juga pernah dikatakan "Kiai Kristen" karena telah mendirikan sekolah dengan cara baru ini. ${ }^{64}$ Pernah pada suatu

\footnotetext{
60 lbid., 37.

$61 \mathrm{lbid}, 83$.

62 Kuntoyo, Kiai Haji Ahmad Dahlan, 83.
}

ketika sekolahnya kedatangan sorang guru ngaji dari Magelang, yang mengejeknya dengan sebutan kiai kafir dan kiai palsu karena mengajar dengan menggunakan alat-alat orang kafir. ${ }^{65}$

Mengingat posisi para tokoh ini yang begitu penting dalang lingkup sosial masyarakat Yogyakarta kala itu, menjadi semakin jelas bahwa secara otomatis orang-orang yang mengikuti gagasan Ahmad Dahlan juga tidak mendapatkan dukungan dari masyarakat. Mereka juga mendapat stigma negatif, dipandang telah menyimpang dari ajaran Islam, atau kafir karena mengikuti gagasan Ahmad Dahlan. Risiko semacam ini dalam pemasaran sosial disebut dengan risiko sosial. Tampak jelas dalam paparan diatas bahwa untuk mengadopsi gagasan pembaharuan pendidikan yang dibawa oleh Ahmad Dahlan ada risiko soal yang sangat besar yang harus diterima para target adopter.

\section{Pengelolaan Risiko Sosial Yang Dilakukan K.H. Ahmad Dahlan}

Sebelum dikelola oleh organisasi Muhammadiyah, sekolah yang didirikan oleh Ahmad Dahlan, dikelolanya sendiri. Namun demikian seiring dengan intensifnya interaksi Ahmad Dahlan dengan anggota Boedi Oetomo, bahkan Ahmad Dahlan sendiri juga telah terdaftar menjadi pengurus, muncullah usulan dari salah seorang anggota Boedi Oetomo untuk mendirikan sebuah wadah yang lebih besar berupa organisasi untuk mengelola sekolah tersebut. Hal ini agar sekolah tersebut dapat

\footnotetext{
63 Majelis Diklitbang dan LPI PP Muhammadiyah, Satu Abad., 27

64 Kuntoyo, Kiai Haji Ahmad Dahlan, 82-83.

65 Sucipto, K.H. Ahmad Dahlan., 126.
} 
terus ada dan berkembang bahkan ketika Ahmad Dahlan sudah tidak ada. ${ }^{66}$ Maka dengan bantuan beberapa tokoh Boedi Oetomo didirikanlah organisasi yang kemudian di beri nama Muhammadiyah.

Melalui pendirian organisasi Muhammadiyah ini pula, Ahmad Dahlan berhasil mengumpulkan banyak dukungan dari masyarakat. Terutama untuk mendukung gagasan pembaharuan di bidang pendidikan yang sedang la perjuangkan. Pendirian organisasi Muhammadiyah adalah memang untuk pengelolaan sekolah Muhammadiyah sebagai wujud konkret pembaharuan di bidang pendidikan. Melalui organisasi ini pula akhirnya dukungan menjadi terformalisasi dan dapat diketahui oleh masyarakat.

Berdasarkan catatan Register der Besluit van der Guverneur General van NedelandschIndie, Buitenzorg, den 22 sten Augustus 1914, Nomor 18, disebutkan bahwa 9 Founding leaders Muhammadiyah yaitu Mas Ketib Amin, Haji Ahmad Dahlan; Mas Penghulu, Abdullat Sirat; Raden Ketib Tjandana, Haji Ahmat; Haji Abdul Rahman, Raden Haji Sarkawi, Mas Gebajan, Haji Mohammad, Raden Haji Djaelani, Haji Anis, Mas Carik, Haji Muhammad Pakih. Deretan nama tokoh tersebut memberikan indikasi penting dalam konteks penelusuran tentang genealogi sosial pendiri Muhammadiyah. Sebagaimana diindikasikan oleh titel aristokrat yang melekat, pada umumnya pendiri Muhammadiyah adalah abdi dalem keraton Yogyakarta. Dilihat dari stastus sosial, banyak peneliti menyebutkan pendukung utama Muhammadiyah adalah

66 Ibid., 27.

67 Majelis Diklitbang dan LPI PP Muhammadiyah, Satu Abad., 27. komunitas santri-priyayi, yaitu kombinasi antara varian santri dan priyayi dalam konteks Clifford Geertz. Dalam konteks Kerajaan Yogyajarta, kelompok santripriyayi mayoritas berdomisili di wilayah yang disebut dengan Kauman.

Setelah Muhammadiyah resmi mendapatkan izin dari pemerintah Belanda, Ahmad Dahlan juga mengumumkan pendirian Muhammadiyah ini pada masyarakat Yogyakarta kala itu. Ahmad Dahlan mengundang perwakilan pemerintah Belanda, tokoh masyarakat, kalangan ulama dan temasuk juga Kiai penghulu (yang pada awalnya menolak menandatangani surat izin pendirian Muhammadiyah) untuk datang ke lapangan dalam rangka mengumumkan pendirian Muhammadiyah. ${ }^{67}$ Selain Ahmad Dahlan, kelompok ini pula yang ikut memberikan pengajaran dalam hal agama di sekolah Muhammadiyah.

Pendukung kedua Muhammadiyah pada periode awal perkembangannya datang dari kaum terpelajar didikan sekolah Belanda. Pada periode awal, beberapa figur terkemuka Muhammadiyah memiliki latar belakang pendidikan Belanda Seperti Raden Soesrosoegondo, Mas Radji, Mas Ngabeni Djojosugito, dan Dr. Soemowidagdo. Tidak seperti kelompok yang disebutkan diatas, kelompok ini tidak bertitel haji dan mempertahankan gelarnya sebagai anggota aristokrat Jawa. Figur-figur tersebut memiliki kontribusi penting dalam perumusan programprogram Muhammadiyah. ${ }^{68}$ Bahkan ikut mengajar pelajaran umum di sekolah Muhammadiyah.

${ }^{68}$ Subhan, Lembaga Pendidikan., 129. 
Sehubungan dengan fakta bergabungnya Ahmad Dahlan dengan Boedi Oetomo, beberapa ahli sejarah berpadangan bahwa sedari awal tujuan Ahmad Dahlan bergabung dengan Boedi Oetomo adalah untuk mencari atau berdakwah pada mereka dan mengajak mengenalkannya pada ajaran Islam yang sesungguhnya. Namun demikian, dalam perjalanannya Ahmad Dahlan kemudian banyak menceritakan gagasan pembaharuannya di berbagai bidang terutama pendidikan yang kemudian mendorong anggota Boedi Oetomo untuk ikut serta mendukung gagasannya tersebut, mengingat kesamaan tujuan dan programnya dengan Boedi Oetomo. ${ }^{69}$

Raden Soesrosoegondo, dalam kapasitasnya sebagai wakil ketua departemen pendidikan Muhammadiyah, memasukan sistem pembelajaran modern ke dalam sekolahsekolah Muhammadiyah. Atas jasa Soesrosoegondo pendidikan agama di sekolah menjadi perhatian Boedi Oetomo. Kemungkinan atas pengaruh figur inilah Ahmad Dahlan menjadi guru agama di Kweekschool Jetis dan OSVIA Magelang. Soesrosoegondo juga ikut mendorong pembukaan sekolah-sekolah yang mengintegrasikan mata pelajaran umum dan agama. ${ }^{70}$

Kelompok pendukung Muhammadiyah yang selanjutnya adalah kelompok muslim pedagang dan enterpreneur. Ahmad Dahlan sendiri diindikasikan sebagai pedagang batik. Diduga jaringan perdagangan yang dimiliki menjadi pendukung gerakan Muhammadiyah. Dukungan dari kaum

69 Majelis Diklitbang dan LPI PP Muhammadiyah, Satu Abad., 33.

70 Subhan, Lembaga Pendidikan., 129. pedagang dan entrepreneur tersebut tampak dari kepengurusan Muhammadiyah di Surabaya, Pekalongan, Pekajangan dan Kotagede. Mereka adalah pedagang batik sukses di Solo dan Pekajangan, pengusaha perak yang sukses di Kotagede, dan pengusaha rokok kretek di Kudus. Merekalah yang kemudian juga banyak mendukung secara finansial kegiatan sekolah Muhammadiyah. ${ }^{71}$

Di Pekalongan, Muhammadiyah dipimpin oleh Ahmad Rasjid (AR) Sultan Mansur, pedagang sukses asal Minangkabau, yang memberi inspirasi pada pedagang Minangkabau lain untuk bergabung dengan Muhammadiyah. Menjadikan kenyataan tersebut sebagai pertimbangan, tidak berlebihan bahwa Muhammadiyah merupakan gerakan Islam yang beranggotakan kelompok-kelompok elit dalam masyarakat, yang dapat dikatakan sebagai kelas menengah muslim yang secara umum berdomisili di perkotaan. ${ }^{72}$ Diketahui pula bahwa memang ternyata Ahmad Dahlan seringkali mengadakan pengajian untuk kelompok ini. Ahmad Dahlan seringkali mengundang para pedagang ke rumahnya kemudian mengadakan kajian bersama. Dalam perjalanan dagangnya, Ahmad Dahlan juga senantiasa menyempatkan berdakwah dan menyebarkan berbagai gagasan pembaharuannya. Tidak mengherankan jika kemudian dukungan juga didapatkan dari kelompok ini.

Berdasarkan fakta diatas dapat diketahui bahwa pihak-pihak yang mendukung gerakan Ahmad Dahlan merupakan

\footnotetext{
71 lbid., 130

72 Ibid., 130
} 
kelompok elit di masyarakat atau tergolong leader opinion. Dalam hal dukungan dari kelompok agamawan misalnya, teridentifikasi bahwa dominasi kelompok pendukung adalah kelompok santri priyayi, priyayi dan para pengusaha. Dengan kondisi masyarakat Yogyakarta kala itu, kelompok ini merupakan golongan dengan status sosial yang tinggi di masyarakat. Kelompok santri priyayi adalah kelompok paling berpengaruh dari karena kredibilitas keagamaan dan derajat kebangsawanannya, kelompok priyayi walaupun mereka tidak memiliki kredibilitas dalam hal agama, namun status kebangsawanan mereka sangat tinggi di masyarakat, terutama para anggota Boedi Oetomo. Mereka juga merupakan kelompok yang banyak memiliki peran sosial di masyarakat, baik dalam hal pendidikan maupun kesehatan dan sosial lainnya. Kelompok pengusaha, dengan kekuatan ekonominya, merupakan kelompok berpengaruh di masyarakat. Mereka adalah pemberi lapangan pekerjaan bagi masyarakat sekitar. Peran itulah yang menempatkan mereka pada status sosial yang tinggi di masyarakat kala itu.

Dari berbagai usaha yang dilakukan oleh Ahmad Dahlan, dapat diketahui bahwa memang Ahmad Dahlan mengupayakan sekali untuk mendapatkan dukungan dari kelompok ini. Untuk mendapatkan dukungan dari kelompok santri priyayi, Ahmad Dahlan banyak melakukan diskusi terkait dengan gagasan pembaharuannya, termasuk dalam bidang pendidikan. Sebagaimana diketahui pula, gerakan Ahmad Dahlan memang pada awalnya merupakan gerakan abdi dalem para santri priyayi. Untuk itu dimasa awal, Ahmad Dahlan banyak melakukan diskusi-diskusi dengan kelompok ini. Formalisasi dukungan dilakukan dengan menjadikan mereka sebagai pengurus inti Muhammadiyah, sebagai organisasi pengelola sekolah yang digagas Ahmad Dahlan.

Di sisi lain bergabungnya Ahmad Dahlan dengan Budi Oetomo, bahkan sampai menjadi pengurus, diketahui berawal dari diskusi-diskusi tentang persoalan pribumi. Dari sana Ahmad Dahlan berkesempatan untuk menjelaskan berbagai gagasan pembaharuannya, terutama dalam hal pendidikan. Terbukti dari proses tersebut, akhirnya Ahmad Dahlan mendapatkan banyak sekali dukungan, baik dalam pendirian sekolahnya di masa awal, pendirian organisasi Muhammadiyah, bahkan sampai dengan pembukaan sekolahsekolah baru Muhammadiyah. Untuk mendapatkan dukungan dari para pengusaha, rupanya pengajian yang dibuat Ahmad Dahlan untuk kelompok pengusaha muslim memang mampu menciptakan dukungan kuat dari kelompok ini. Melalui pengajiannya itulah Ahmad Dahlan banyak menyampaikan konsep pembaharuannya, termasuk dalam bidang pendidikan.

Berdasarkan beberapa fakta di atas, menunjukan bahwa untuk mendapatkan dukungan dari kelompok leader opinion di masyarakat, Ahmad Dahlan banyak melakukan diskusi-diskusi tentang konsep pembaharuannya di bidang pendidikan. Ahmad Dahlan mengangkat persoalan dan keprihatinannya pada nasib muslim dan pribumi sebagai latar belakang pergerakannya. Sebagaimana karakteristik leader opinion yang seringkali tertarik dengan isu sosial semacam ini, menjadi sangat wajar jika kelompok-kelompok ini, akhirnya tertarik dan memberikan dukungan maksimal pada gerakan Ahmad 
Dahlan. Pencarian dukungan dari berbagai kelompok elit masyarakat diatas merupakan bagian dari upaya pengelolaan risiko sosial dalam mengadopsi gagasan pembaharuan Ahmad Dahlan di bidang pendidikan. Risiko sosial yang tinggi akibat sikap para pemuka agama yang terang-terangan menolak sekolah Ahmad Dahlan ini dijawab oleh Ahmad Dahlan dengan cara mengumpulkan dukungan sosial dari pihak lain yang juga memiliki pengaruh besar di masyarakat Yogyakarta kala itu.

Dalam hal pengelolaan dukungan untuk mendorong proses penerimaan gagasan pembaharuan dan menurunkan risiko sosial yang dihadapi masyarakat dalam mengadopsi gagasan pembaharuan yang ditawarkan, Ahmad Dahlan mengumumkan pendirian Muhammadiyah di lapangan terbuka yang dihadiri oleh leader opinion dengan turut mengundang masyarakat umum bahkan kelompok penentang. Melalui proses ini masyarakat akhirnya dapat mengetahui bahwa Muhammadiyah termasuk juga program-program kependidikannya telah mendapatkan dukungan dari para leader opinion mereka. Hal tersebut membuat masyarakat yang awalnya takut menerima gagasan pembaharuan di bidang pendidikan Ahmad Dahlan, menjadi setidaknya mengetahui bahwa para leader opinion atau elit sosial mereka banyak yang mendukung gagasan pendidikan Ahmad Dahlan. Sehingga risikorisiko sosial yang dikhawatirkan dapat terminimalisir.

Selanjutnya untuk semakin menguatkan, Ahmad Dahlan juga melibatkan langsung para leader opinion pada program pendidikannya, baik dalam hal kepengajaran pelajaran agama, pelajaran umum maupun pembukaan sekolah maupun pendanaan. Ini akan semakin menunjukan pada masyarakat bahwa dukungan dari para leader opinion tersebut tidak main-main. Dari tangan para leader opinion inilah pembaharuan pendidikan ini benar-benar lahir. Sehingga seharusnya para target adopter tidak lagi merasa perlu khawatir. Bukankah selama ini para leader opinion itu juga yang diikuti dan merekapun telah percaya.

Berkat berbagai usaha dan pengelolaan dukungan ini pulalah akhirnya sampai akhir 1920 gagasan pembaharuan pendidikan yang ditawarkan oleh K.H. Ahmad Dahlan dapat diterima secara luas oleh masyarakat. Hal tersebut dapat diinidkasikan dari perkembangan jumlah siswa dan sekolah Muhammadiyah yang meningkat dari 20 orang menjadi 787 orang di tahun 1920. Fakta tersebut semakin menguatkan bahwa usaha pengelolaan yang dilakukan mampu menjawab risiko sosial yang menghambat masyarakat menerima gagasan pembaharuan bidang pendidikan.

\section{Kesimpulan}

Dalam menyebarkan gagasan pembaharuannya di bidang pendidikan K.H. Ahmad Dahlan mendapat tantangan berupa adanya risiko sosial yang tinggi, yang harus ditanggung oleh target adopter akibat penolakan keras gagasannya tersebut oleh para pemuka agama yang menjadi rujukan masyarakat dan memiliki wewenang dari Sultan Yogyakarta untuk mengurusi bidang keagamaan. Berkurangnya jumlah santri Ahmad Dahlan, juga jumlah murid yang sangat sedikit di awal merupakan indikasi kuat sulitnya masyarakat dalam menerima gagasan pembaharuan pendidikan yang dibawa oleh Ahmad Dahlan. 
Pengelolaan risiko sosial dalam cost of adoption gerakan pembaharuan K.H. Ahmad Dahlan dalam bidang pendidikan, dilakukan dengan menggalang dukungan sosial dari para elit atau leader opinion masyarakat. Kelompok elit yang dimaksud adalah kelompok santri priyayi, priyayi, dan pengusaha. Mereka dipilih karena merupakan leader opinion di masyarakat Yogyakarta kala itu. Usaha-usaha tersebut dilakukan dengan berbagai langkah seperti mengajak mereka diskusi gagasan pembaharuan yang ditawarkan, mengadakan pengajian khusus untuk kelompok tertentu, dan sebagainya. K.H. Ahmad Dahlan memahami betul bahwa mereka, para kelompok elit sosial, tertarik dengan ide-ide baru yang bersifat kemajuan masyarakat. Untuk itulah ide-ide produk sosial pembaharuan pendidikan yang ditawarkan dapat diterima.

Untuk mengukuhkan dukungan tersebut, K.H. Ahmad Dahlan juga menunjukan keterlibatan aktif dari para leader opinion pada berbagai program pembaharuan Pendidikan yang digagasnya kepada masyarakat luas. Hal tersebut mampu menurumkan risiko sosial yang muncul akibat stigma negatif yang dibangun oleh pihak penentang. Keberhasilan penggalangan dukungan sosial tersebut berefek sangat siginifikan bagi penerimaan gagasan pembaharuan pendidikan Ahmad Dahlan. Ditandai dengan jumlah murid sekolah Muhammadiyah yang meningkat pesat.

Dari hasil studi ini, para aktivis dakwah dapat mengambil pelajaran terkait pentingnya aktivitas pengelolaan risiko sosial dalam cost of adoption produk sosial keagamaan yang ditawarkannya. Para pelaku dakwah perlu memikirkan berbagai usaha agar risiko-risiko tersebut dapat diatasi, sehingga mitra dakwah tidak merasa berat atau terhambat dalam proses pengadopsian nilai-nilai Islam dewasa ini.

\section{Bibliografi}

Adnan, Ricardi S. Target Adopter Transformasi Pemasaran Sosial: Yang Mengubah Wajah Indonesia. Jakarta: UI Press, 2012.

Anshoriy, HM Nasruddin, Matahari Pembaharuan: Rekam Jejak KH. Ahmad Dahlan. Yogyakarta, JB Publisher, 2010.

Arifin, MT. Gagasan Pembaharuan Muhammadiyah dalam Pendidikan. Jakarta: Dunia Pustaka Jaya, 1987.

Arlen, Defti dkk, Thought KH. Ahmad Dahlan In the Field of Social and Educational. Tesis, Universitas Lampung, 2014.

Darban, Adaby. Sejarah Kauman; Menguak Kampung Muhammadiyah. Yogyakarta, Persatuan 2000.

Koda, Fauji, The History of Muhammadiyah's Thought and Movement, Study on Personality and Idea of The Founding Figure (KH. Ahmad Dahlan). International Journal of Scientific \& Technology Research, 8, 2017. 
Kotler, Philip dan Eduardo L. Roberto. Social Marketing: Strategies for Changing Public Behavior. New York: The Free Press, 1989.

Kotler, Philip. and Zaltman, Sosial Marketing: An Approach to planned sosial change. Journal of Marketing, August, 1971

Kuntoyo, Sutrisno. Kiai Haji Ahmad Dahlan dan Perserikatan Muhammadiyah. Jakarta: Balai Pustaka 1998.

Lefebvre, R. Craig. Social Marketing and Social Change: Strategies and Tools for Health, WellBeing and Environtment. California, Jossey-Bass:2013.

Lubis, Arbiah. Pemikiran Muhammadiyah dan Muhammad Abduh. Jakarta: Bulan Bintang, 1989.

Majelis Diklitbang dan LPI PP Muhammadiyah. Satu Abad Muhammadiyah: Gagasan Pembaharuan Sosial Keagamaan. Jakarta: Kompas, 2010.

Mulkhan, Abdul Munir. Pemikiran K.H. Ahmad Dahlan dan Muhammadiyah dalam perspektif Perubahan Sosial. Jakarta: Bumi Aksara, 1990.

Muriah, Siti. Metodologi Dakwah Kontemporer. Yogyakarta: Mitra Pustaka, 2000.

Nata, Abuddin. Sejarah Pertumbuhan dan Perkembangan Lembaga-lembaga Pendidikan Islam di Indonesia. Jakarta: PT. Gramedia Widiasarana, 2001.

Poespa, Margono. Gerakan Islam Muhammadiyah. Yogyakarta, Percetakan Persatuan, 1983.

Priyono, AE. Paradigma Islam - Interpretasi Untuk Aksi: Kuntowijoyo. Bandung: Mizan Media Utama, 2008.

Rohmaenah, Yutandes Titin. "Kampung Kauman Yogyakarta: Studi Tentang Perkembangan Muhammadiyah (1912-1923)", Skripsi, UNY, 2010.

Rogers, Everett M. Diffusion of Innovation. New York: The Free Press, 1983.

Ruswan, "Colonial Experience and Muslim Educational Reforms: A comparation of the Aligarh And the Muhammadiyah Movements", Tesis, McGill University, 1997.

Salam, Junus. Gerakan Pembaharuan Muhammadiyah. Tangerang: Al-Wasat Publising House, 2009.

Setyani, Christina Andhika, "10 Alasan Perempuan Enggan Berhijab", KOMPAS.com.

Shobahiya, Mahasri. Studi Kemuhammadiyahan; Kajian Historis, Ideologi dan Organisasi. Surakarta: LPID UMS, 2008.

Sitepu, Susianti BR, Pemikiran Teologi K.H. Ahmad Dahlan. Tesis, Universitas Negeri Sumatra Utara, 2016.

Subhan, Arief. Lembaga Pendidikan Islam Indonesia Abad Ke-20, Jakarta: UIN Jakarta Press, 2009.

Sucipto, Hery. K.H. Ahmad Dahlan Sang Pencerah, Pendidik dan Pendiri Muhammadiyah. Jakarta: Best Media Utama, 2010.

Suyoto, dkk. Pola Gerak Muahmmadiyah Ranting. Yogyakarta: UMG Press, 2005.

Syamsuddin, Din. Muhammadiyah Kini dan Esok. Jakarta: Pustaka Panjimas, 1990.

Tofik, Nor. Pemikiran K.H. Ahmad Dahlan Dalam Pembaharuan Pendidikan Islam di Indonesia. Yogyakarta: UIN. 1992.

Wadi, Husnan, Strategi Pegembangan Dakwah K.H. Ahmad Dahlan Di Yogyakarta Dan TGH. Muhammad Zainuddin Abdul Majid di Lombok. Tesis, Universitas Muhammadiyah Surakarta, 2012. 